\title{
ABYSSES OF FIRE
}

Rafael Santana*

\section{RESUMO}

Trata-se de artigo que visa a pensar a gênese da poesia no universo artístico de Mário de Sá-Carneiro, poeta que empreende a sua crítica literária no seio da própria escritura ao fazer dela um espaço de reflexão sobre as especificidades da arte. Elegendo como precursoras algumas figuras hiper-representativas da modernidade tais como Baudelaire, Rimbaud e Mallarmé, Sá-Carneiro inscreve a sua poesia na esteira de toda uma linhagem de poetas transgressores, para quem a escrita se configura sobretudo como um corpo a corpo com a linguagem.

PALAVRAS-CHAVE: Mário de Sá-Carneiro, Modernismo, Poesia Portuguesa do Século XX.

\section{ABSTRACT}

The aim of this paper is to think the genesis of the poetry in the artistic universe of Mário de Sá-Carneiro, a poet who undertakes literary criticism from within his own writings while reckoning with the specificities of art. Following the path of some of the iconic figures of modern times, such as Baudelaire, Rimbaud and Mallarmé, Sá-Carneiro inscribes his poetry in a tradition of a whole lineage of poets for whom writing is above all a hand-to-hand with language.

KEYWORDS: Mário de Sá-Carneiro, Modernism, Twentieth Century Portuguese Poetry. 
Para Teresa Cerdeira, que me ensinou a ver na linguagem literária um espaço de promessas, encantos e amavios.

Revisito minha memória cultural. Assalta-me de repente o verso de uma canção popular brasileira: "Mora na filosofia: pra que rimar amor e dor?". Verdadeira lição de teoria literária, aprendo com esta música que o trabalho formal não é apenas um mero adorno despiciendo; aprendo que, em se tratando da poesia, o jogo rítmico contribui - e muito - para a construção do próprio eixo semântico do poema, e que por isso mesmo rimar amor e dor seria uma tautologia necessária, nunca anódina! Vem-me à cabeça outra canção popular. Decido utilizá-la como mote das reflexões que aqui pretendo desenvolver. Os versos que dela mais me interessam dizem o seguinte: "A burguesia fede / A burguesia quer ficar rica / Enquanto houver burguesia / Não vai haver poesia”. Encontro-me pois diante de uma letra forte, provocativa, como costumam ser muitas das letras de Cazuza. Prontamente contrasto ambas as melodias e percebo que, ao passo que a primeira demarca uma similaridade conceitual entre amor e sofrimento, a segunda acentua uma disparidade consensual entre poesia e comércio. Se a rima consoante entre amor e dor nos põe frente a conceitos que se coadunam, a rima - também consoante - entre burguesia e poesia parece colocar-nos, muito pelo contrário, frente a um contrassenso aparentemente insolúvel: burguesia combina com poesia ou vice-versa?

Octavio Paz, poeta-crítico que não poucas vezes se debruçou em reflexões sobre as especificidades do poético, afirma, já em sua primeira obra teórica de grande impacto, que a poesia moderna, inserida que está no seio da sociedade capitalista, não abdicou, muito surpreendentemente, dos sortilégios do arco e da lira, como se poderia num primeiro momento imaginar. Se o tempo da produção em massa é em princípio um tempo inóspito à poesia porque mormente interessado no valor da troca e do lucro imediatos, o exercício poético surgiria nesse mesmo tempo reificado como um gesto de resistência diante das afrontas do mundo mercadológico. Não por acaso o crítico mexicano sinalizou, com extrema perspicácia, que "a poesia moderna se converteu no alimento dos dissidentes e desterrados do mundo burguês" (2012, p. 48).

Em Portugal, país que goza de uma larguíssima tradição lírica de indiscutível qualidade, o desafio de conciliar os valores burgueses mais pragmáticos com o dispêndio algo característico da poesia ${ }^{2}$ foi pressentido e comentado já na primeira metade do século XIX, quando um artista como Almeida Garrett se perguntava: "Pois este é um século para poetas? ou temos nós poetas para este século?...” (2013, p. 72). Ao postular o seu lugar na primeira tertúlia oitocentista portuguesa como o de um Poeta em anos de prosa, Garrett está também a erigir um questionamento: como dizer a poesia - aqui entendida a partir das coordenadas do idealismo romântico - num século de barões corruptos, precisamente traidores dos mais belos 
ideais que herdara dos projetos humanitários do Iluminismo e da Revolução Francesa? Se a prosa foi considerada na sociedade de oitocentos como uma forma mais apta a atender à demanda de uma produção que se queria em larga escala, em outras palavras, se ela foi compreendida como mais propícia a educar uma sociedade nova que consigo trazia a novidade de um público-leitor mais abrangente, onde e como ficaria agora, nesse tempo novo e com um público diverso, o espaço a ser destinado à poesia? Acusando o século de barões de ser chato, vulgar e sensabor, ou melhor, frisando, de outro modo, que a burguesia fede por valorizar apenas o lucro, as cifras, o papel, o vil metal, Garrett aponta a sua angústia em relação ao aparente descompasso entre burguesia e poesia.

Não era ainda o tempo das revoluções poéticas de Baudelaire. E talvez Garrett não se tivesse dado conta de que para ser lírico no auge do capitalismo ou, ainda benjaminianamente, de que para escrever poesia num período em que a arte se encaminhava para a era de sua reprodutibilidade técnica, era preciso que o poeta se desvencilhasse de sua aura, de sua profética coroa, tornando-se anônimo ao imiscuir-se na massa informe e caótica da cidade cosmopolita. E aqui nos encontramos novamente frente a um impasse! Como dizer o espírito cosmopolita em Portugal, território marcado por uma cultura periférica diante das grandes potências da Europa industrializada? Eis o desafio que, no que tange à poesia, coube a Cesário Verde enfrentar.

Ciente do aparente descompasso ou, para dizer com Camões, do desconcerto entre burguesia e poesia, Cesário buscou revitalizar o verso lírico, conferindo-lhe forma e conteúdos até então inusitados na tradição poética portuguesa. Pensando o modo muito particular como o autor de "O sentimento dum ocidental" se apropria dos postulados de Baudelaire para adequá-los lúcida e criticamente ao contexto de uma cultura periférica, Leyla Perrone-Moisés se pergunta: "Seria Cesário a prova de que uma poesia moderna enquadrada e normalizada é possível?” (2000, p. 129). A esse instigante questionamento, acrescento - mais que motivadamente uma provocação de Jorge Fernandes da Silveira: "No fundo, os poemas de Cesário expõem contundentemente a tentativa de encontrar os termos (impossível?) para a rima consoante entre burguesia e poesia" (2003, p. 158-159). Refletindo sobre a pergunta de Leyla Perrone-Moisés e sobre a afirmação interrogativa de Jorge Fernandes da Silveira, eu ousaria dizer que, ao apostar na força de trabalho como um elemento articulador de mudanças, Cesário Verde é, no contexto da literatura portuguesa finissecular, o exemplo mais concreto da possibilidade de articular uma poesia moderna inserida no princípio burguês da ética do trabalho. Encontrando os termos possíveis para a rima consoante entre burguesia e poesia, Cesário compõe "um livro que exacerb[a]" e ultrapassa tão radicalmente a concepção poética de seu tempo histórico que apenas os poetas de Orpheu, no início do século XX, seriam capazes de destacar a modernidade de sua obra, que rompe com toda uma longa tradição lírica portuguesa de veio sentimental. Ao compor em poemas pequenas narrativas de passeio nas quais o 
leitor não raras vezes se depara com a criação de personas fictícias - sujeitos ficcionais pobres, "quase Jó[s]" - que em nada se assemelham ao abastado autor empírico Cesário Verde, este poeta inegavelmente moderno está a um passo da heteronímia pessoana, não fosse que, como afirma Helder Macedo, "os heterónimos de Pessoa são projecções da sua consciência de si próprio; as personae de Cesário são caracterizadas no contexto" (1999, p. 25). Respondendo ao processo de autognose da pátria ${ }^{3}$, que desde Garrett vinha sendo empreendido no Portugal do século XIX, Cesário revitaliza o projeto humanitário das utopias oitocentistas de um modo espantosamente heterodoxo, abrindo a cena de uma nova modernidade estético-poética em Portugal.

Cesário Verde é de fato um poeta seminal para os artistas de Orpheu, e assim também para Mário de Sá-Carneiro, escritor que em princípio dizia considerar-se apenas um prosador e não um poeta. Com efeito, na obra sá-carneiriana Cesário aparece como referência intertextual explícita desde Princípio (1912), a primeira coletânea de novelas que Sá-Carneiro publicou em vida. Nela o poema Ironias do desgosto exerce a função de mote do conto intitulado Loucura, cujo enredo se resume grosso modo a uma tentativa de driblar o fluxo do tempo, no intuito de fixar espasmodicamente os efêmeros instantes de beleza. Não me interessa contudo deter-me na análise desta narrativa. Interessa-me antes pensar a gênese da poesia no universo literário de Sá-Carneiro, e, para tanto, inevitável se faz retornar a Cesário Verde.

Posicionando-se sempre como o líder de sua geração, Fernando Pessoa disse esta frase - hoje já célebre - integrando-se a um nós coletivo: Cesário ensinou-nos a ver. Ora, Sá-Carneiro aprendeu também ele a ver com Cesário, de modo a imitar a sua temática e o seu estilo no poema "Simplesmente", reintitulado, num segundo momento, de "Partida" (1913). Ao empreender o processo de reescrita deste poema que em princípio se dividia em duas partes, Sá-Carneiro decidira elidir todo o seu primeiro movimento ${ }^{4}$, mais imitativo do estilo do poeta de "Esplêndida", afirmando: "E a imitação de Cesário Verde - como se tratava na ocasião dum puro divertimento sem amanhã - foi propositada! Mau gosto, é claro. Mas eu estava a brincar. Simplesmente da brincadeira nasceu uma coisa com algumas belezas. E aproveitei-a” (1995, p. 758).

Reagindo, num processo algo semelhante ao da heteronímia pessoana, à sua inexistência enquanto Sá-Carneiro diante dos temas e do estilo típicos de Cesário, o futuro autor de Dispersão assinalaria ainda em sua correspondência literária: "Resolvi substituir toda a primeira parte do 'Simplesmente' por esta única quadra:

Ao ver passar a vida mansamente

Nas suas cores serenas, eu hesito,

E detenho-me às vezes na torrente

Das coisas geniais em que medito".

(1995, p. 775) 
E, modificando ainda mais o poema, Sá-Carneiro chegaria finalmente à sua última versão:
Ao ver escoar-se a vida humanamente
Em suas águas certas, eu hesito,
E detenho-me às vezes na torrente
Das coisas geniais em que medito.
(1996, p. 9)

Se a rasura proposital que Cesário empreendera em sua leitura antropofágica da lírica baudelairiana foi a de urdir uma poesia moderna que contudo não rejeita a ética do trabalho - e que por isso mesmo reitera, de modo bastante crítico, é claro, as utopias mais saudáveis do mundo burguês (lembre-se, por exemplo, o cheiro salutar e honesto a pão no forno) -, Sá-Carneiro, indo voluntariamente ao encontro de Baudelaire e dos estetas finisseculares, fala em sua poesia, a um só tempo, com e contra Cesário. É bem essa a natureza da resposta um tanto ambígua que em 1914 ele dera em entrevista, ao ser indagado sobre as principais obras da então moderna literatura portuguesa. Diante de tal questionamento, eis as suas considerações: "Frisantemente, o livro do futurista Cesário Verde, ondulante de certo, imenso de Europa, ziguezagueante de esforço" (apud Martins, 1990, p. 195). Como bem sinalizou Óscar Lopes (1995), a sedução inicial de Sá-Carneiro por Cesário acabou por converter-se num repto, gesto laudatório e corruptor que simboliza antes de tudo uma aposta contra o autor de "Cristalizações". Por outras palavras, se o sujeito lírico de Cesário quase sempre mantém o seu olhar agudamente focado na vida humana e em seu quotidiano - que deseja devassar por meio do real e da análise -, Sá-Carneiro, em via oposta, elege deambular e divagar narcisicamente pelos labirintos de si próprio, com vistas a contemplar, em onanismo, a genialidade de suas próprias ideias.

Pensar Sá-Carneiro e seus pares é tarefa fundamental para que se possa estabelecer uma leitura mais aprofundada de sua poesia. Diferentemente de Pessoa, o poeta de Manucure não escreveu textos críticos sobre a literatura e as outras artes; tampouco nos deixou uma carta semelhante à da gênese dos heterônimos, epístola que, hoje bem o sabemos, pode e deve ser lida na clave do jogo ficcional, e é bem por aí que já estou a enveredar. Até onde se sabe, Sá-Carneiro escreveu apenas ficção, no sentido mesmo etimológico do termo, e por isso mais amplo, de fingimento, de invenção. Com efeito, grande parte de sua correspondência literária configura-se como uma longa ficção epistolar. Lá estão inscritas as suas ideias para contos e novelas, para projetos futuros e, até mesmo, certas concepções poéticas daquele que inicialmente insistia em dizer escrever poesia por puro diletantismo: "Como há escritores que nas suas horas vagas são pintores, eu, nas minhas horas vagas, sou poeta - na expressão de escrever rimadamente, apenas. Eis tudo" (Sá-Carneiro, 1995, p. 749). A esta carta endereçada a Pessoa, datada de 26 de fevereiro de 1913, segue-se outra, bem próxima, de 10 de março do mesmo ano, em que Sá-Carneiro retoma o 
conceito de poeta-diletante: "Enfim, para mim, entre a poesia e a 'literatura' há a mesma diferença que entre estas duas artes e a pintura, por exemplo. As minhas horas de ócio são ocupadas, não a pintar, como o Bataille, mas a fazer versos. Puro diletantismo" (Ibidem, p. 758).

Ora, sabemos que nem Sá-Carneiro nem a maioria dos artistas de sua geração fizera da literatura e das artes um instrumento de trabalho, se considerarmos o vocábulo em seu viés mais pragmático. Convém lembrar aliás que Sá-Carneiro nunca trabalhou nem converteu a sua atividade literária num meio de sobrevivência material, como foi o caso de um Camilo Castelo Branco, por exemplo. Decerto que Cesário Verde, poeta que antes mesmo de Sá-Carneiro sofrera a dor da incompreensão - "A crítica segundo o método de Taine / Ignoram-na" (2003, p. 52) - tampouco obteve lucros com a sua poesia. "Um prosador qualquer desfruta fama honrosa / Obtém dinheiro, arranja a sua coterie", dirá ele, acrescentando: "E a mim, não há questão que mais me contrarie / Do que escrever em prosa" (Ibidem). Todavia, se em Cesário a ética do trabalho é ainda uma aposta no futuro, em Sá-Carneiro ela será antes o lugar da recusa: “Ganhar o pão do seu dia / Com o suor do seu rostó... / - Mas não há maior desgosto / Nem há maior vilania" (1995, p. 102). Para o autor de Indícios de oiro, os pilares principais da sociedade burguesa - que são o indivíduo, a família conjugal e a ética do trabalho -pertenciam todos eles ao mundo dos lepidópteros, termo que utilizava para qualificar as pessoas insensíveis e de espírito vulgar, em suma, para qualificar os burgueses.

Cesário Verde também sabia, como Sá-Carneiro, que a burguesia fede e que o capitalismo avassalador submetera a poesia a um incontornável estado de crise. Mas a meu ver a diferença mais significativa entre ambos os artistas está na capacidade que o poeta finissecular tivera de fazer erigir a força épica das varinas em meio ao fedor do peixe podre a gerar focos de infecção. Mesmo diante do artificialismo desumanizador e asfixiante da cidade, mesmo diante das disparidades sociais, mesmo diante da ruína do presente, Cesário ainda aposta no trabalho como uma atividade regeneradora do homem e, metonimicamente, da própria nação. Em resumo: se em Cesário há, ao fim e ao cabo, uma aposta no útil, em Sá-Carneiro há, muito pelo contrário, um proposital gozo no inútil.

Claro está que a gênese da atividade poética não se encontra, no universo literário de Sá-Carneiro, exatamente no poema "Partida", o primeiro do conjunto de 12 textos que em vida publicara sob o título de Dispersão. Os seus chamados Primeiros poemas - vários deles, inclusive, bastante piegas - fazem parte, muito justificadamente, de sua obra completa, como que a atestar as iniciativas titubeantes de escrever poesia por parte de um adolescente talentoso. No entanto, é necessário salientar que quando compôs diversos dos seus Primeiros poemas Sá-Carneiro ainda não havia tido o privilégio de desfrutar da experiência parisiense. Ao transferir-se para a grande capital latina em finais de 1912 com a escusa de estudar Direito na Sorbonne, o jovem escritor recém-chegado de uma Lisboa que 
declaradamente rejeitava - por considerá-la uma cidade provinciana e de espírito filisteu - entrega-se em Paris a uma existência de diletantismo, travando conhecimento, no espaço cosmopolita da metrópole francesa, com figuras ímpares como Santa Rita Pintor, bem como com tendências literárias diversas, tais como o decadentismo reverberante, o cubismo deslocador de sentidos e o modernismo em ascensão. A esse respeito, recorde-se ainda a já referida carta a Pessoa, de 10 de março de 1913, em que Sá-Carneiro ensaia estas reflexões sobre o cubismo e, mais largamente, sobre as estéticas de vanguarda:

\begin{abstract}
No entanto, confesso-lhe, meu caro Pessoa, que, sem estar doido, eu acredito no cubismo. Quero dizer: acredito no cubismo, mas não nos quadros cubistas até hoje executados. Mas não me podem deixar de ser simpáticos aqueles que, num esforço, tentam em vez de reproduzir vaquinhas a pastar e caras de madamas mais ou menos nuas - antes, interpretar um sonho, um som, um estado de alma, uma deslocação do ar, etc. Simplesmente levados a exageros de escola, lutando com as dificuldades duma ânsia que, se fosse satisfeita, seria genial, as suas obras derrotam, espantam, fazem rir os levianos. Entretanto, meu caro, tão estranhos e incompreensíveis são muitos dos sonetos admiráveis de Mallarmé. E nós compreendemo-los. Por quê? Porque o artista foi genial e realizou a sua intenção. Os cubistas talvez ainda não a realizassem. Eis tudo (1995, p. 754-755, grifos do autor).
\end{abstract}

A investida contra aqueles que intentam reproduzir vaquinhas a pastar e caras de madamas mais ou menos nuas em suas telas é, na concepção de Sá-Carneiro, o traço mais distintivo - e por isso mesmo mais admirável - do cubismo. Se a pintura cubista é capaz de causar no leitor/ espectador a sensação de torpor advinda de uma conjunção que se estabelece paradoxalmente através da desconjuntura de suas formas; e mais, se as figuras plasmadas na tela cubista podem ser lidas como qualquer coisa de intermédio porque propositadamente compostas para causar naqueles que as contemplam o impacto da confusão e, por conseguinte, do deslocamento dos sentidos, note-se que muita dessa interpretação sá-carneiriana sobre o cubismo adentra a própria materialidade de sua escrita, desejosa de dizer os sonhos, os sons, os estados complexos de alma, as deslocações do ar, enfim. E repare-se que a esse suposto indizível, a esse aparente estado de inefabilidade, Sá-Carneiro vem acrescentar - justificada e motivadamente - a voz sedutora e obsedante de Mallarmé, artista que revolucionou a linguagem poética de seu tempo ao levá-la não raro até ao paroxismo da incompreensão. Por ser - perdoem-me a anacronia - barthesianamente consciente de que mudar a língua pode por vezes significar mudar o mundo, Mallarmé fizera de sua experiência na poesia uma espécie de laboratório no qual a maquinaria de linguagem, diga-se, o construto estético do texto, era levado a um quase limite da explosão ${ }^{5}$. Rechaçando as cristalizações da linguagem, ou melhor, rejeitando as comodidades do discurso, o autor de "Um lance de dados" compõe uma obra cujos sentidos escapam a qualquer leitura que 
se queira imediata. Dir-se-ia, com Barthes, que o poema mallarmeano é um espaço de palavras no qual os sentidos estão sempre deslocados, em suspenso, recusando-se deste modo ao dogmatismo, aos estereótipos, ao fascismo da língua.

Aos olhos de Sá-Carneiro os poemas de Mallarmé afiguram-se como verdadeiras telas capazes de baldar os sentidos, por promoverem o deslocamento do olhar do leitor que se aventura num mergulho profundo neste imenso e revolto mar de palavras. Insisto no significante tela porque foi precisamente através desta imagem que Sá-Carneiro pensou compor pela primeira vez - e ficcionalmente - as suas próprias teorias sobre a linguagem poética. Quando esboçou o projeto de escrita do conto "Asas" (1914), texto que é ao fim e ao cabo uma teoria da poesia ${ }^{6}$, ele revelou a Fernando Pessoa, em carta datada de 7 de janeiro de 1913, um pouco daquilo que já começava a delinear-se como as suas novas ideias artísticas:

Acerca de ideias novas, esta nascida ontem à noite: um artista busca a perfeição - é esta a sua tortura máxima e desfaz e refaz a sua obra. Vence: atinge a perfeição e continua a querer fazer maior: porém, a tela em que trabalha evola-se por fim, dilui-se, torna-se espírito - desaparece. Esse artista ultrapassou a perfeição. É possível que em vez dum pintor faça dele um músico. Não dou a isto, por enquanto, grande importância. Diga você a sua opinião (1995, p. 734, grifos do autor).

Não será o protagonista deste conto futuro nem um pintor nem um músico, como era a proposta primeira de Sá-Carneiro, mas sim um poeta. Em nova carta a Pessoa, datada de 21 de janeiro de 1913, Sá-Carneiro reestrutura o projeto inicial desta sua narrativa, modificando os rumos de seu enredo. Eis então o que se define:

"Asas" - É a história do artista que busca a perfeição e a ultrapassa sem a conseguir atingir (além-perfeição). Eu dava a este conto - cuja ideia lhe expus outro dia - o título de "Asas", querendo simbolizar a perfeição que não se pode atingir, porque, ao atingi-la, evola-se, bate asas (1995, p. 740).

Se o projeto inicial do conto pressupunha a aventura pelos campos da pintura ou da música, a teoria poética a ser desenvolvida ao longo deste texto que tivera seu curso modificado pressupõe agora uma espécie de excursão pelas diversas áreas do saber através do intermédio da literatura, espaço plural que, como magistralmente apontou Roland Barthes em sua aula inaugural no Collège de France, nunca parte da arrogante prerrogativa de saber alguma coisa mas sim da generosidade de saber de alguma coisa.

Ao considerar as especificidades da poesia, Sá-Carneiro declara o intuito de conferir aos seus versos uma "beleza plástica" (Ibidem, p. 749). Por outras palavras, ao poeta interessa trabalhar não só com ideias mas "também com o som das frases" (Ibidem), plasmando no próprio corpo do poema, dirá ele, "a harmonia que existe nos passos da dança" (Ibidem, p. 
763). Repare-se pois que as artes plásticas, a linguagem literária, a música e o balé convergem para a formação da teoria poética de Sá-Carneiro, teoria que se quer ela própria atravessada, interseccionada, pelo elemento pictural, pela melopeia, pelos ritmos musicais, pelos movimentos leves e céleres da bailadeira. Assim é que Petrus Ivanowitch Zagoriansky - esse é o nome do poeta-protagonista do conto "Asas" - materializa no espaço da escrita este seu corpo quase etéreo de ideias fluidas:

- Acredite-me, cada vez melhor me convenço de que a atmosfera é uma fonte inesgotável de beleza inúmera. Convém que nós, os artistas, aprendamos, hora a hora, a devassá-la... Saber a Distância! compreender o Ar... o espaço, que nunca é imóvel - e vibra sempre, coleia sempre... A mínima oscilação, só por si, vale um motivo de Arte - é uma beleza nova: zebrante, rangente, desconjuntada e emersa... Fantasie um corpo nu, magnífico, estendido sobre colchas da Índia, em um atelier de luxo... Mas de volta, meu amigo, de volta, tudo será esse corpo - só a beleza purificada desse corpo!... Soçobrará o resto, desarticular-se-á em redor, focado o ambiente nessa apoteose - alabastros de convergência!... Depois é o próprio corpo que, de tanto haver concentrado, se desmorona em catadupas de oscilações afiladas, loiras, viciosas... Abrem os seios gomos de ar crispado, as pernas derrotam colunatas - agitam os braços múltiplas grinaldas; os lábios palpitam incrustações de beijos... Tudo se abate de Beleza! E o corpo é já um montão de ruínas, de destroços de ar, que ondeiam livres, em vórtice - e se emaranham, se entrecruzam, se desdobram, se convulsionam... Todo o ar vive esse corpo $n u !(1995$, p. 485-486)

Para além das múltiplas pulsações sinestésicas que aí promovem a convulsão por meio da con-fusão de todos os sentidos - "Os meus poemas são para se interpretarem com todos os sentidos” (1995, p. 491) - acentua Zagoriansky -, o que poderia levar-nos a pensar na tradição simbolista de um Rimbaud ou de um Verlaine, por exemplo, para além dessas múltiplas pulsações sinestésicas, repito, o que mais de perto me interessa destacar neste excerto é a consciência que nele se exacerba do texto enquanto corpo erótico, edifício de linguagem, construto de palavras. Desejoso, tal qual Mallarmé, de promover uma espécie de alquimia, diga-se, de transmutação da matéria vil em essência pura capaz de dizer a ideia mesma e suave da flor ausente de todos os buquês, ou seja, de formular uma linguagem poética autocentrada, que, assim como os passos da bailadeira, se voltasse autotelicamente para si mesma, Sá-Carneiro empreende, pelos sortilégios da ficção, o exercício de outrar-se através da máscara de um poeta russo vanguardista - e lembremos que a vanguarda russa era por ele assumida como um grande elemento de sedução!

Ora, se o lugar da linguagem muitas vezes se configura para o escritor como o próprio espaço da sedução, aqui entendido etimologicamente como o lugar do desvio, não será difícil inferir que o que seduziu o olhar de 
Sá-Carneiro tanto para as vanguardas quanto para a poesia de um Baudelaire, de um Rimbaud e de um Mallarmé foi sempre a "possibilidade de uma nova linguagem que [esses] outro[s] lhe oferec[iam]" (Perrone-Moisés, 2006, p. 18). A perda da aura, a "vidência" lograda através do desregramento dos sentidos e a poesia que se pensa enquanto construção são temas recorrentes na literatura sá-carneiriana. Esta consciência da autorreferencialidade da arte permite que Sá-Carneiro compreenda o texto - muito barthesianamente - como um "anagrama do corpo" (2006, p. 24), como um envoltório fendido, em outras palavras, como uma pele a ser voluptuosamente percorrida em todas as suas zonas erógenas. Daí o erotismo pujante com que ele formula esta sua teoria da poesia - seios, pernas, braços e lábios são convocados nesta reflexão sobre o poético, como que a definir de outro modo, com outra linguagem, o conceito proposto por Octavio Paz, para quem "o erotismo é uma poética corporal e a poesia uma erótica verbal” (1994, p. 12).

Na teoria da poesia desenvolvida em "Asas", texto cujo título sugere algo de tão leve e de tão etéreo como o vento, um narrador em primeira pessoa isenta-se de narrar a sua própria história em prol da história de um outro, apresentando-nos a personagem de Petrus Ivanowitch Zagoriansky, poeta russo ficcional que almeja lograr a construção de versos perfeitos, sobre os quais a gravidade não tenha ação. Trata-se, como já se disse, de um texto que promove toda uma reflexão sobre a arte, em especial a poesia, e, para o caso, a arte e a poesia modernas, inscritas nas correntes cosmopolitas, historicamente próximas ou mesmo contemporâneas de Sá-Carneiro. Datado de outubro de 1914 mas tendo sido publicado em pequenos fragmentos desde janeiro de 1913, o conto "Asas" é certamente um ensaio em prosa, é o desenvolvimento da teoria poética que daria origem aos poemas mais significativos de Sá-Carneiro, que integram os conjuntos Dispersão, Indícios de oiro e Últimos poemas. No conto, o poeta Zagoriansky está em busca de uma arte fluida:

- Uma arte fluida, meu amigo, uma arte gasosa... Melhor, meu amigo, melhor - gritava-me Zagoriansky no seu gabinete de trabalho, aonde pela primeira vez me recebia - uma arte sobre a qual a gravidade não tenha ação!... Os meus poemas... os meus poemas... Mas ignora ainda! Coisa alguma prenderá os meus poemas... Quero que oscilem no ar, livres, entregolfados - transparentes a toda a luz, a todos os corpos - sutis, imponderáveis... E hei-de vencer!... Não atingi a Perfeição, por enquanto... Bem sei, restam escórias nos meus versos... Por isso a gravidade ainda atua sobre eles... Mas em breve... em breve... ah!... (Sá-Carneiro, 1995, p. 490, grifos do autor).

Repare-se no uso do vocábulo escórias para definir a impossibilidade de alcançar perfeição poética. No fundo e na superfície, Sá-Carneiro já refletia sobre a poesia desde 1913, quando de fato começou a escrever poemas mais seriamente. A busca do ouro absoluto é uma constante de sua obra, e não é por acaso que ele pretendia reunir, sob o título alegórico ${ }^{7}$ de 
Indícios de oiro (conjunto publicado postumamente por iniciativa dos presencistas), alguns dos poemas que publicou, em 1915, no primeiro número da revista Orpheu. Ora, sabemos que as escórias são os resíduos que se formam aquando da fusão dos metais, e Indícios de Oiro é um título motivado, que aponta a um só tempo para a busca incompleta e para o logro parcial do metal lavrado. Fundindo palavra com palavra, Sá-Carneiro promove a união dos seus metais-metáfora no texto, visando a alcançar o máximo grau de abstração através da poesia. Em toda a obra sá-carneiriana, reitero, há como que uma busca incansável pelo ouro absoluto, do qual a realidade exterior oferece apenas pequeníssimos indícios.

Buscando "obter a Perfeição - 'esse fluido"' (1995, p. 490), Zagoriansky quer plasmar uma arte gasosa compondo poemas em que as palavras estão tão milimetricamente encaixadas - e formando um conjunto tão harmônico - que a introdução de qualquer outro elemento faria desmoronar todo o construto do texto. Na busca de escrever poesia com ideias, com sons, com sugestões de ideias e com intervalos, Zagoriansky intenta estetizar o volátil por meio da formulação de uma poética do ar, que propaga a ânsia de reproduzir o acelerado movimento do mundo moderno através de palavras leves e céleres. Ao fim e ao cabo, o poeta russo ficcional repensa a ética e a estética da poesia, na busca de poemas que lograssem inscrever simultaneamente a intensidade da vida moderna e o olhar inebriado do indivíduo que transita em vertigem pela cidade caótica e sedutora, lançando-se em meio a multidões, cafés, bulevares, music halls, fábricas titânicas, automóveis velozes e notícias de última hora, rapidamente divulgadas em todos os meios de comunicação. É esta modernidade do movimento que Zagoriansky quer alcançar na poesia, deparando-se não raro com a imperfeição, com o vácuo da escrita.

Desde a primeira página do texto, o russo é apresentado como um ser vago, litúrgico e ungido pelo mistério. Seduzido por ele, o narrador do conto torna-se um grande amigo do poeta e de sua família, com quem goza as horas de lazer. Os anos passam e Zagoriansky continua a polir os seus versos, cuja perfeição nunca é atingida. Um dia, inesperadamente, ele afirma ter enfim concluído a sua obra, sobre a qual a gravidade já não atuava mais. Para a surpresa do narrador - que almejava ler aquela que seria a escritura mais original e genial do mundo -, o caderno de versos do poeta encontrava-se praticamente vazio, restando dela apenas um curto trecho introdutório. "Todos os meus versos, libertos enfim, tinham resvalado do meu caderno - por voos mágicos!...” (1995, p. 495), revela Zagoriansky. Como numa espécie de "feitiço medieval", "de envoûtement de missa negra...” (Ibidem) - as expressões são do próprio narrador - os poemas ter-se-iam imaterializado, a representar, simbolicamente, os amavios da linguagem.

Não estamos longe das reflexões de Blanchot em A parte do fogo. Discorrendo aí sobre a literatura e o direito à morte, o teórico francês faz-nos perceber que o literário "se edifica sobre suas ruínas" (1997, p. 292), 
o que pressupõe portanto a aceitação do falível, do precário, do inacabado. Refletindo oximoricamente sobre a escrita e o lugar do vazio, Blanchot assinala ainda que o nada da escrita é inusitadamente o lugar onde "tudo começa a existir: grande prodígio" (Ibidem).

O estágio de perfeição atingido pelo poeta russo criado por Sá-Carneiro coincide com o desaparecimento de sua obra e com a intensificação de sua loucura (mortes por metáfora). Em outros termos, é a morte, é o vazio das palavras, que as torna paradoxalmente plenas de sentido, porque o "vazio é seu próprio sentido" (Ibidem, p. 300). Consciente de que a linguagem literária é feita de inquietudes, Blanchot chega à conclusão de que "Somente a morte me permite agarrar o que quero alcançar; nas palavras, ela é a única possibilidade de seus sentidos. Sem a morte, tudo desmoronaria no absurdo e no nada" (Ibidem, p. 312). E é precisamente com uma morte figurada que a obra do poeta Zagoriansky se realiza desaparecendo.

Em Da soberba da poesia (2012), Marcos Siscar também se debruça em reflexões sobre a linguagem e a crise, assinalando que a poesia moderna, de Baudelaire a Mallarmé, dos modernistas aos surrealistas, pressupõe uma inevitável experiência da queda ou do afundamento. Se os artistas finisseculares e modernos assumiram não raro a máscara da frivolidade e da indiferença, escrevendo e inscrevendo-se sob o signo da rareza - "O meu destino é outro - é alto e é raro", dizem os versos de Sá-Carneiro (1996, p. 11) - isto não pressupõe contudo que eles (os artistas) tivessem gozado do privilégio de um eterno "estar nas alturas" ou do alcance da totalidade, pois é dramatização da consciência do falhanço, o gesto sacrificial e teatralizado de esmagar-se a si próprios, que caracteriza a experiência da soberba do poeta e da poesia modernos. Para terminar gostaria de propor uma leitura para o poema "A queda", que encerra em gradação descendente o conjunto de Dispersão:

E eu que sou o rei de toda esta incoerência,

Eu próprio turbilhão, anseio por fixá-la

E gira até partir... Mas tudo me resvala

Em bruma e sonolência.

Se acaso em minhas mãos fica um pedaço d’ouro,

Volve-se logo falso... ao longe o arremesso...

Eu morro de desdém em frente dum tesouro,

Morro à míngua, de excesso.

Alteio-me na cor à força de quebranto,

Estendo os braços d’alma - e nem um espasmo venço!...

Peneiro-me na sombra - em nada me condenso...

Agonias de luz eu vibro ainda entanto.

Não me pude vencer mas posso-me esmagar,

- Vencer às vezes é o mesmo que tombar -

E como inda sou luz num grande retrocesso, 
Tombei...

E fico só esmagado sobre mim!...

(1996, p. 31)

Dispersão inicia-se motivadamente com o poema intitulado "Partida" e encerra-se não menos motivadamente com o poema "A queda", fazendo-nos pensar numa espécie de movimento pendular que se constrói todo ele em alternâncias constantes de anábases e catábases. Se "Partida", poema que, como vimos, recebera num primeiro momento o título de "Simplesmente" e que se configurava como uma imitação dos temas e do estilo típicos de Cesário Verde, se caracteriza desde as suas primeiras estrofes como um metafórico trajeto em gradação ascendente - É subir, é subir além dos céus; É partir sem temor contra a montanha; Sombra, vertigem, ascensão, Altura -; "A queda" se constitui não menos alegoricamente como o fim de um itinerário figurado, de uma desregrada viagem onírica e orgiástica que, à moda de Rimbaud, se mostra também ela ciosa de lograr uma vidência outra, que ultrapassasse a mera percepção precária e limitada dos sentidos corporais. Esse gozo sá-carneiriano no excesso - capaz de sacudir loucura, de suscitar cores endoidecidas e portanto de promover uma ultrapassagem das limitações do senso comum - parece ter o seu modelo no pequeno poema rimbaudiano justamente intitulado "Départ" (Partida), no qual se lê: "Assez vu. La vision s'est rencontrée à tous les airs. / Assez eu. Rumeurs des villes, le soir, et au soleil, et toujours. / Assez connu. Les arrêts de la vie. - Ô Rumeurs et Visions ! / Départ dans l'affection et le bruit neufs ${ }^{8 \text { " }}$.

A experiência do excesso permite ao sujeito que se entrega à orgia do desregramento sensorial o alcance de uma vidência outra, a contemplação de um saber outro, que contudo não se faz perene e/ou absoluto: saber demais, no que concerne a Rimbaud; saber a Distância; compreender o Ar, no que tange a Sá-Carneiro. A consciência do precário, do transitório, do falhanço é aliás uma das coordenadas sempre presentes na poesia finissecular e moderna, que tão bem releu Baudelaire. Na obra de Sá-Carneiro, seja ela em verso ou em prosa, a figura do artista insurreto, teatralmente avesso às limitadas convenções sociais, mostra-se sempre na ânsia de alcançar uma aura outra, insubmissa ${ }^{9}$, capaz de reconsagrá-lo profanamente através da perversidade, da subversão, da transgressão. $O$ que Baudelaire um dia ousou nomear de beleza maldita Sá-Carneiro classificou em seu tempo como beleza errada, considerando assim a falha, a errância discursiva e a morte como categorias inseparáveis do fenômeno poético da modernidade. Foi o logro da beleza errada, o disse ele próprio, a mira final de sua obra. 
Petrus Ivanowich Zagoriansky, o poeta russo fictício que é afinal a máscara através da qual Mário de Sá-Carneiro dissemina as suas próprias teorias poéticas, fascina e inebria o narrador do conto "Asas", "impressionando-[o] muito o seu aspecto aureolado" (1995, p. 484), a sua aura insubmissa. Vago e disperso, Zagoriansky manifesta a ânsia de ultrapassar os parcos limites da sensorialidade vulgar, com vistas a alcançar no espaço da escrita aquela sonhada - mas sempre impossível - Grande Obra que lograsse fixar o fugidio e o errante de uma atmosfera sempre em movimento. Suas "frases de chama" (Ibidem, p. 489), violentas, excessivas, desassossegadas, que se inscrevem evidentemente numa modernidade que tem em Baudelaire, Rimbaud e Mallarmé os seus paradigmas, cumprem um percurso não menos significativo que é o do alegórico sacrifício da vítima, que neste caso não é outra senão o próprio poeta. Do grego allos (outro) + gourein (discurso), a alegoria é etimologicamente o discurso-outro. O processo discursivo da alterização, do devir-outro, é portanto um modo alegórico de escrever o eu e de estar na linguagem. Exacerbando a consciência da ruína, diga-se, da impossibilidade do centramento de um discurso unívoco, a alegoria é espaço movediço par excellence, atmosfera-linguagem onde os signos se encontram em constante processo de deslizamento, recusando-se à fixação. Se a poesia baudelairiana se inscreve num trânsito dinâmico entre spleen e ideal (ascensão e queda) e na experiência autodestrutiva de descer ao fundo do abismo para encontrar a novidade do desconhecido, não nos esqueçamos de que a poesia finissecular e moderna, herdeira de Baudelaire, pressupõe ela também a descida ao inferno em Rimbaud e a não menos abismal experiência “DO FUNDO DUM NAUFRÁGIO” em Mallarmé.

É essa volúpia no esmagamento, na alegórica e voluntária vitimização do artista capaz de converter o discurso de um eu disperso no discurso de um outro embrionariamente heteronímico - qualquer coisa de intermédio - que Sá-Carneiro valoriza em sua obra. Baudelaire sinalizou em "Le Voyage" (A Viagem): "Nous voulons, tant ce feu nous brûle le cerveau, / Plonger au fond du gouffre, Enfer ou Ciel, qu'importe? / Au fond de l'Inconnu pour trouver du nouveau !10". Em Sá-Carneiro o impulso autodestrutivo alegorizado na descida ao fundo do abismo tem a sua variante incontornável no signo fogo, que no poeta de Dispersão ultrapassa o lugar da mera referência isolada, ganhando o peso de uma métaphore filée. É na costura dessa grande tela-tecido composta de reluzentes fios de ouro em ininterrupto processo de combustão que Sá-Carneiro alegoriza a vida e a obra dos artistas iconoclastas da modernidade, que, desejosos de assinalar a poesia de suas próprias existências insurretas, exercem em si próprios a violência de mergulhar nos abismos de fogo. Em palavras suas: "Efêmero ouro que se volve em labareda a perverter..." (1995, p. 499).

\section{REFERÊNCIAS BIBLIOGRÁFICAS}

BARTHES, Roland. O prazer do texto. Trad. J. Guinsburg. São Paulo: Perspectiva, 2006. 
. Aula. Trad. Leyla Perrone-Moisés. São Paulo: Cultrix, 2007.

BATAILLE, Georges. A parte maldita: precedido da noção de despesa. Trad. Miguel Serras Pereira. Lisboa: Fim de Século, 2005.

BLANCHOT, Maurice. A parte do fogo. Rio de Janeiro: Rocco, 1997.

BENJAMIN, Walter. Obras escolhidas. Charles Baudelaire: um lírico no auge do capitalismo. Trad. José Carlos Martins Barbosa \& Hemerson Alves Baptista. São Paulo: Brasiliense, 2000.

. Origem do drama barroco alemão. Trad. Sérgio Paulo Rouanet. São Paulo: Brasiliense, 1984.

GARRETT, Almeida. Viagens na minha terra. Coordenação da edição e prefácio de Sérgio Nazar David. Rio de Janeiro: Nova Fronteira, 2013.

LOURENÇO, Eduardo. O labirinto da saudade. Lisboa: Gradiva, 2010.

LOPES, Óscar. Mário de Sá-Carneiro ou a aposta contra Cesário. In: Santos, Gilda et al. (org.). Cleonice, clara em sua geração. Rio de Janeiro: UFRJ, 1995, p. 566-582.

MARTINS, Fernando Cabral. Pessanha e Sá-Carneiro: intersecções. In: Colóquio/Letras n. 117-118. Lisboa: Setembro-Dezembro de 1990, p. 193-199.

PAZ, Octavio. O arco e a lira. Trad. Ari Roitman \& Paulina Wacht. São Paulo: Cosac Naify, 2012.

. A dupla chama: amor e erotismo. Trad. Wladyr Dupont. São Paulo: Siciliano, 1994.

PERRONE-MOISÉS, Leyla. Flores da escrivaninha: ensaios. São Paulo: Companhia das Letras, 2006.

. Inútil poesia. São Paulo: Companhia das Letras, 2000.

SENA, Jorge de. Estudos de literatura portuguesa - II. Lisboa: Edições $70, \mathrm{~s} / \mathrm{d}$.

SILVA, Edson Rosa da. Da impossibilidade de cantar e de contar: um olhar benjaminiano sobre a literatura. In: Semear n.10. Rio de Janeiro: PUC-RJ, 2004, p. 93-106.

SILVEIRA, Jorge Fernandes da. Cesário, duas ou três coisas. In: Silveira, Jorge Fernandes da. (org.). Verso com verso. Coimbra: Angelus Novus, 2003, p. 153-166.

SISCAR, Marcos. Da soberba da poesia: distinção, elitismo, democracia. São Paulo: Lumme Editor, 2012.

Poesia e crise. Ensaios sobre a crise da poesia como topos da modernidade. São Paulo: UNICAMP, 2010. 
SÁ-CARNEIRO, Mário de. Poesia de Mário de Sá-Carneiro. Organização de Fernando Cabral Martins. Lisboa: Presença, 1996.

Obra completa. Organização, introdução e notas de Alexei

Bueno. Rio de Janeiro: Nova Aguilar, 1995.

VERDE, Cesário. O livro de Cesário Verde. São Paulo: L\&PM, 2003.

\author{
Recebido para publicação em 29/05/2015 \\ Aprovado em 22/08/2015
}

\title{
NOTAS
}

*Professor Adjunto de Literatura Portuguesa da Universidade Federal do Rio de Janeiro (UFRJ); Doutor em Literatura Portuguesa pela mesma universidade, onde defendeu a tese intitulada Lições do Esfinge Gorda, sobre a prosa e a correspondência literária de Mário de Sá-Carneiro. Atua principalmente nos seguintes temas: Decadentismo, Modernismo e ecos do fim de século na literatura contemporânea. Tem artigos publicados no Brasil e no exterior. CV Lattes: http://lattes.cnpq.br/3361786514654494

2 Que fique claro que subjazem a estas reflexões alguns argumentos de Georges Bataille (2005), para quem a poesia ocupa o lugar do luxo, das despesas inúteis e/ou excedentes, se compreendida a partir da lógica utilitária do mundo do trabalho.

3 Utilizo o termo cunhado por Eduardo Lourenço em O labirinto da saudade.

4 Óscar Lopes acentua que “[...] a juvenília lírica, novelística e dramática de Sá-Carneiro não se afasta muito da tradição realista; a novela Loucura (Princípio) inspira-se num poema de Cesário [...] Mas mais significativo é o seguinte facto: o poema Partida, que inicia o seu primeiro livro de versos, Dispersão, e que se apresenta como sendo uma sua introdução, foi originariamente concebido e escrito como um poema em duas partes, com o título geral de Simplesmente; a primeira parte é eliminada na redacção definitiva e, como factilmente se reconhece e o autor declara [...], não passa de uma 'imitação de Cesário Verde', onde se imagina a vida 'honesta, sã, trabalhadeira' de uma rapariga que o autor diz ter visto numa rua de Paris; a segunda parte reage contra o realismo e a simpatia social dessa imitação e exalta uma escalada 'em busca da beleza', 'até além dos céus', numa linguagem que nas estrofes iniciais parece meramente saudosista, mas que acaba por definir o estilo pessoal de Sá-Carneiro, com as suas metáforas exaltadas e megalómanas e a sua profusão de sinestesias" (1995, p. 574, negritos meus).

5 Marcos Siscar, poeta e crítico cujos trabalhos mais recentes se têm focado no tema poesia e crise, acentua que "Se os momentos altos da poesia da tradição (baseados na repetição métrica ou rítmica) são descritos como 'orgíacos excessos', a poesia do presente, em seu estado de sombra e arrefecimento, para Mallarmé, seria a poesia dos 'deliciosos quases', bem ao gosto da Decadência fin-de-siècle. [...] A operação mallarmeana é muito diferente da operação destruidora e bélica da vanguarda, que deseja operar uma ruptura, um corte com a tradição" (2010, p. 108-109).

6 Numa brevíssima nota de 1952, Jorge de Sena já apontava para uma leitura nesse sentido. Ei-la: "Segundo Sá-Carneiro, «a Arte do russo residia no timbre cromático ou aromal do som de cada frase e no movimento peculiar a cada 'circunstância' dos seus poemas». Descontada a fraseologia pretensamente impressionista, tão típica de Sá-Carneiro e de todas as revistas efémeras do seu tempo, isto aplica-se quase exactamente, como é obvio, ao poeta extraordinário que Sá-Carneiro se preparava para ser. E o dizê-lo de um «outro» que se inventa é muito daquela geração com os seus Caeiros, Campos, Violantes de Cysneiros, etc., admiravelmente teorizados no «Ultimatum» de Álvaro de Campos. Simplesmente a heteronímia, tão plena e vitoriosamente conseguida por Fernando Pessoa, como expiação da alteridade do mundo moderno que nele próprio se espelhava, era em Sá-Carneiro menos um «movimento peculiar a cada 'circunstância' dos seus poemas», que em Pessoa o foi; 
e mais, de facto, o timbre desesperado de uma alteridade irresoluta «eu não sou eu nem sou o outro»". E irresoluta, por profundamente incerta na própria natureza do poeta e não na da sua poesia, que, miraculosamente, com uma originalidade que ninguém no mundo pode disputar-lhe, transformou em imagens fulgurantes, de um equilíbrio que só certo dandysmo perturbou, a mais trágica consciência de frustração que já houve em Portugal” (s/d, p. 181-182, grifos do autor).

7 Utilizo o termo alegoria em seu sentido benjaminiano de desvio da doxa, de oposição à associação imagética algo cômoda e imediata que, para o teórico alemão, caracterizaria o símbolo.

8 "Vi demais. A visão se reencontrou em toda parte. / Tive demais. Sons das cidades, à noite, e ao sol, e sempre. / Soube demais. As paradas da vida. - Ó Rumores e Visões! / Partida para a afeição e o ruído novos!”. (Trad. minha).

9 O conceito de aura insubmissa foi cunhado por Edson Rosa da Silva que, a propósito de Baudelaire, assinala: "A poesia lírica da modernidade joga por terra a aparência da beleza, põe às claras sua carcaça e sua decomposição. Busca, no entanto, um meio de reencontrar seu brilho, sua forma e sua essência divina, através de uma aura insubmissa que, apesar de tudo, da técnica, da ideologia burguesa e do valor de mercado, ainda pode garantir a magia do poeta" (2004, p. 106, grifos do autor).

10 "Nós queremos, tanto esse fogo nos queima o pensamento, / Mergulhar no fundo do abismo, Inferno ou Céu, que importa? / No fundo do Desconhecido para encontrar o novo". (Trad. minha). 